\title{
Controle judicial das políticas públicas
}

\author{
Leandro José da Silva ${ }^{1}$
}

\section{Resumo}

Temos visto no Judiciário, atualmente, um papel ativo na vida institucional brasileira. Todavia, esse ativismo judicial, ora aplaudido, ora criticado, deve ser visto com ressalvas. De fato, a atuação do Poder Judiciário, embora algumas vezes necessária, não pode invadir o campo de atuação dos demais Poderes, sob pena de comprometer a democracia e representar a judicialização da política, como já advertiu Carl Schmitt. Assim, o mérito das políticas públicas, atinente à competência do Poder Executivo, deve ficar fora do controle jurisdicional. O objeto do presente estudo será, assim, estabelecer os limites do controle judicial em relação às políticas públicas.

Palavras-chave: Democracia. Constitucionalismo. Ativismo judicial. Autolimitação. Política pública.

\section{Introdução}

A atuação do Poder Judiciário, em algumas questões, tem sido objeto de grandes polêmicas. O debate polariza-se entre aqueles que defendem a sua atuação livre e sem limites, e outros que pregam a sua autolimitação.

O ativismo, entendido como "[...] uma postura a ser adotada pelo magistrado que o leve ao reconhecimento da sua atividade como elemento fundamental para o eficaz e efetivo exercício da atividade jurisdicional", ${ }^{2}$ tem sido objeto de resistências em face da possível ofensa ao princípio da separação de poderes, consagrado no segundo artigo da Constituição da República.

1 Advogado da União. Especialista em Direito Processual Civil. Mestrando pela PUC/PR.

2 DELGADO, José Augusto. Ativismo Judicial: o papel político do poder judiciário na sociedade contemporânea. In: JAYME, Fernando Gonzaga; FARIA, Juliana Cordeiro de; LAUAR, Maira Terra. Processo civil novas tendências: homenagem ao professor Humberto Theodoro Júnior. Belo Horizonte: Del Rey, 2008. p. 319. 
O ativismo judicial é uma atitude, ou seja, a escolha de um modo específico e proativo de interpretar a Constituição, expandindo o seu sentido e alcance. ${ }^{3}$

A separação ou divisão de poderes significa que cada órgão é especializado no exercício de uma função, cabendo às assembleias (Congresso, Câmara, Parlamento) a função legislativa, ao Poder Executivo, a função executiva e ao Poder Judiciário, a função jurisdicional. ${ }^{4}$

Outro problema atualmente em debate é a judicialização de questões políticas, ocasião em que o Poder Judiciário decide controvérsias de natureza política, o que, aparentemente, também ofende o princípio da separação de poderes.

É verdade que a judicialização, ainda que excessiva, é fenômeno inerente ao nosso estado democrático de direito, o qual a lei não excluirá da apreciação do Poder Judiciário lesão ou ameaça a direito, conforme disposto no art. $5^{\circ}$, inciso XXXV da Constituição da República.

Assim, por meio do princípio da inafastabilidade do controle jurisdicional,

[...] todos têm acesso à justiça para pleitear tutela jurisdicional preventiva ou reparatória a lesão ou ameaça de lesão a um direito individual, coletivo, difuso ou até individual homogêneo. Constitui, portanto, um direito público subjetivo, decorrente da assunção estatal de administração da justiça, conferido ao homem para invocar a prestação jurisdicional, relativamente ao conflito de interesse qualificado por uma pretensão irresistível. ${ }^{5}$

3 BARROSO, Luís Roberto. Judicialização, ativismo judicial e legitimidade democrática. Revista Atualidades Jurídicas, Brasília, n. 4, p. 6, jan./fev. 2009. Disponível em: <http:// www.oab.org.br/oabeditora/users/revista/123506667017421 8181901.pdf>. Acesso em: 30 ago. 2010.

4 SILVA, José Afonso da. Curso de direito constitucional positivo. 19. ed., rev. e atual. São Paulo: Malheiros, 2001. p. 113.

5 BULOS, Uadi Lammêgo. Constituição federal anotada. 3. ed., rev. e atual. São Paulo: Saraiva, 2001. p. 178. 
Como visto, a judicialização faz parte do amadurecimento da sociedade, que está cada vez mais ciente de seus direitos e não poupa esforços em recorrer ao Judiciário quando eles forem desrespeitados.

O problema não está na judicialização excessiva, que até pode ser considerada benéfica do ponto de vista da conscientização dos direitos, mas sim na judicialização de questões que não deveriam ser levadas à esfera do Poder Judiciário. $\mathrm{Na}$ verdade, o problema reside na aceitação dessas controvérsias pelo Judiciário, bem assim na assunção da responsabilidade de resolvê-las, quando deveriam ser remetidas ao foro competente.

Conforme frisou Canotilho, “[...] os juízes devem autolimitar-se à decisão de questões jurisdicionais e negar a justiciabilidade das questões políticas”. ${ }^{6}$ As questões políticas, atinentes à competência do Poder Executivo, devem ficar fora do controle jurisdicional.

O objeto do presente estudo será, então, analisar a necessidade da autolimitação judicial, com o propósito de evitar o desenfreado ativismo judicial e a judicialização de questões que não deveriam ser levadas à esfera do Poder Judiciário.

\section{0 embate entre constitucionalismo e democracia}

A polêmica entre constitucionalismo e democracia remonta ao século passado, oportunidade em que o filósofo alemão Carl Schmitt escreveu a obra "Der Hüter der Verfassung” (O Guardião da Constituição), defendendo que somente o Presidente do Reich, em conformidade com o artigo 48 da Constituição de Weimar, teria legitimidade para representar os desejos do povo alemão. ${ }^{7}$

6 CANOTILHO, José Joaquim Gomes. Direito constitucional e teoria da constituição. 7. ed. Coimbra: Almedina, 2003. p. 1309.

7 SCHMITT, Carl. La defensa de la Constitución. Madrid: Tecnos, 1998. p. 213-251. 
Em desacordo com a tese sustentada por Schmitt, o filósofo austro-americano Hans Kelsen publica o ensaio intitulado "Wer soll der Hüter der Verfassung sein?” (Quem deve ser o guardião da Constituição?), em que defende a ideia da necessidade de um Tribunal Constitucional para exercer a guarda da Constituição. ${ }^{8}$

Kelsen prega a existência de um tribunal constitucional independente dos demais Poderes do estado, uma vez que,

[...] seria naturalmente necessário, porém, exigir que o tribunal constitucional a que caberia julgar as leis e regulamentos da União e dos estados federados proporcionasse, por sua composição paritária, garantias de objetividade suficientes, e se apresentasse não como um órgão exclusivo da União ou dos estados federados, mas como o órgão da coletividade que os engloba igualmente, da Constituição total do Estado, cujo respeito seria encarregado de assegurar. ${ }^{9}$

Ao polemizar com Schmitt, Kelsen

[...] procura demonstrar o caráter ideológico das teses do Professor de Berlim, resultante da confusão entre ciência e política e, em um sentido mais circunscrito, entre teoria jurídica e teoria política. Kelsen se ocupa de resguardar a defesa da Constituição ante o defensor proposto por Schmitt, pois segundo afirma "nadie puede ser juez de su propia causa". ${ }^{10}$

Schmitt, ao defender a legitimidade do Presidente do Reich para representar o povo e defender a Constituição, entende que a atribuição de soluções judiciais a problemas políticos apenas traz prejuízos ao Poder Judiciário, pois representa mais uma "politização da justiça" do que uma "judicialização da política", sendo que a política nada tem a ganhar e a justiça tem tudo a perder. ${ }^{11}$

8 KELSEN, Hans. Jurisdição constitucional. São Paulo: M. Fontes, 2007. p. 239-298.

9 KELSEN, Hans. Jurisdição constitucional. São Paulo: M. Fontes, 2007. p. 184-185.

${ }^{10}$ MALISKA, Marcos Augusto. Acerca da legitimidade do controle da constitucionalidade. Justitia, São Paulo, v. 63, n. 193, p. 81-96, jan./mar. 2001. Disponível em: <http://bdjur.stj. gov.br/dspace/handle/2011/23783 >. Acesso em: 09 jun. 2010.

${ }^{11}$ SCHMITT, Carl. La defensa de la Constitución. Madrid: Tecnos, 1998. p. 57. 
Assim, em conformidade com o artigo 48 da Constituição de Weimar ${ }^{12}$, o único que teria legitimidade para representar o povo seria o Presidente do Reich, que significaria a confluência dos anseios sociais do povo alemão.

Para Kelsen, todavia, reservar a defesa da Constituição ao Presidente do Reich ou ao Parlamento seria inconveniente,

[...] uma vez que justamente nos casos mais importantes de violação constitucional Parlamento e governo são partes litigantes, é recomendável convocar para a decisão da controvérsia uma terceira instância que esteja fora desse antagonismo e que não participe do exercício do poder que a Constituição divide essencialmente entre Parlamento e governo. $^{13}$

\section{Segundo Luís Roberto Barroso,}

[...] a idéia de Estado democrático de direito, consagrada no art. $1^{\circ}$ da Constituição brasileira, é a síntese histórica de dois conceitos que são próximos, mas não se confundem: os de constitucionalismo e de democracia. Constitucionalismo significa, em essência, limitação do poder e supremacia da lei (Estado de direito, rule of law, Rechtsstaat). Democracia, por sua vez, em aproximação sumária, traduz-se em soberania popular e governo da maioria. ${ }^{14}$

O constitucionalismo é a teoria que, baseada em uma constituição rígida, busca resultados garantísticos, ainda que isso importe em limitação dos demais poderes, possuindo, como pedra angular,

12 Texto do artigo 48 da Constituição de Weimar:

"Quando um Estado (Land) não cumpre os deveres que lhe são impostos pela Constituição ou pelas leis do Reich, o Presidente do Reich pode obrigá-lo com ajuda da força armada. Quando, no Reich alemão, a ordem e a segurança públicas estão consideravelmente alteradas ou ameaçadas, o Presidente do Reich pode adotar as medidas necessárias para o restabelecimento da segurança e ordem públicas, inclusive com ajuda da força caso necessário. Para tanto, pode suspender temporariamente, em todo ou em parte, os direitos fundamentais consignados nos artigos 114, 115, 117, 118, 123, 124 e 153.

De todas as medidas que adote com fundamento nos parágrafos $1^{\circ}$ e $2^{\circ}$ deste artigo, $\mathrm{o}$ Presidente do Reich deverá dar conhecimento ao Parlamento".

${ }^{13}$ KELSEN, Hans. Jurisdição constitucional. São Paulo: M. Fontes, 2007. p. 275.

${ }^{14}$ BARROSO, Luís Roberto. Curso de direito constitucional contemporâneo: os conceitos fundamentais e a construção do novo modelo. São Paulo: Saraiva, 2009. p. 87-88. 
[...] os direitos fundamentais que, por sua vez, representam os valores substantivos escolhidos pela sociedade no momento constituinte - de máxima manifestação da soberania popular - que garantem o funcionamento da democracia, isto é, quando os direitos fundamentais impõem limites materiais aos atos de governo, estão na verdade, a proteger o povo como um todo e não apenas maiorias eventuais. E quem está incumbido de proteger estes valores é o Poder Judiciário, conforme determinação do próprio poder constituinte. ${ }^{15}$

A democracia procedimental funda-se na defesa do procedimento democrático, privilegiando os direitos que garantem participação política e processos deliberativos justos, independentemente do resultado a ser alcançado. ${ }^{16}$

A tensão existente entre o princípio democrático e a jurisdição constitucional encontra-se, assim, na medida em que o primeiro privilegia a vontade popular, independentemente dos resultados obtidos, e a segunda defende a prevalência da norma constitucional, ainda que em detrimento da vontade do povo.

As perguntas que desafiam a doutrina e a jurisprudência podem ser postas nos termos seguintes: por que um texto elaborado décadas ou séculos atrás (a Constituição) deveria limitar as maiorias atuais? E, na mesma linha, por que se deveria transferir ao Judiciário a competência para examinar a validade de decisões dos representantes do povo? ${ }^{17}$

Todavia, a guarda da Constituição pelo chefe de estado não garantiria a imparcialidade, uma vez que "[...] a eleição do chefe de Estado, que se dá inevitavelmente sob a alta pressão de ações político-partidárias, pode ser um método democrático de nomeação, mas não lhe garante particularmente a independência”."18

${ }^{15}$ BARBOZA, Estefânia Maria de Queiroz. Jurisdição constitucional: entre constitucionalismo e democracia. Belo Horizonte: Fórum, 2007. p. 50.

${ }^{16}$ BARBOZA, Estefânia Maria de Queiroz. Jurisdição constitucional: entre constitucionalismo e democracia. Belo Horizonte: Fórum, 2007. p. 25.

${ }^{17}$ BARROSO, Luís Roberto. Curso de direito constitucional contemporâneo: os conceitos fundamentais e a construção do novo modelo. São Paulo: Saraiva, 2009. p. 88.

${ }^{18}$ KELSEN, Hans. Jurisdição constitucional. São Paulo: M. Fontes, 2007. p. 283. 
Ademais, conferir legitimidade para a guarda da Constituição ao chefe de Estado ofenderia o princípio segundo o qual ninguém pode ser juiz em causa própria, especialmente porque, nos casos mais importantes de violação constitucional, parlamento e governo são partes litigantes.

Assim, ambos os regimes apresentam inconvenientes, uma vez que a democracia procedimental não respeita a vontade das minorias, enquanto o constitucionalismo pode gerar decisões destituídas de legitimidade.

Por outro lado, ambos apresentam qualidades, pois somente no constitucionalismo podem ser respeitadas as decisões das minorias em face da possibilidade de decisões contramajoritárias, sendo que na democracia procedimental respeita-se a vontade do povo.

A verdade é que,

[...] sobre a jurisdição constitucional já se disse praticamente tudo, seja para defendê-la, seja para criticá-la. Para o bem ou para o mal, parece que não podemos viver sem ela, pelo menos enquanto não descobrirmos nenhuma fórmula mágica que nos permita juridificar a política sem ao mesmo tempo, e em certa medida, politizar a justiça. ${ }^{19}$

Embora a tese de Kelsen tenha sido a vencedora, no sentido de a guarda da Constituição caber a um tribunal constitucional, sendo adotada tanto no Brasil como na maior parte dos países, é possível compatibilizar a jurisdição constitucional com a democracia procedimental, bastando que seja observado o princípio da autolimitação judicial.

\section{0 ativismo judicial}

Segundo Luís Roberto Barroso,

${ }^{19}$ MENDES, Gilmar Ferreira; COELHO, Inocêncio Mártires; BRANCO, Paulo Gustavo Gonet. Curso de direito constitucional. 4. ed. rev. e atual. São Paulo: Saraiva, 2009. p. 155. 
[...] a idéia de ativismo judicial está associada a uma participação mais ampla e intensa do Judiciário na concretização dos valores e fins constitucionais, com maior interferência no espaço de atuação dos outros dois Poderes. A postura ativista se manifesta por meio de diferentes condutas, que incluem: (i) a aplicação direta da Constituição a situações não expressamente contempladas em seu texto e independentemente de manifestação do legislador ordinário; (ii) a declaração de inconstitucionalidade de atos normativos emanados do legislador, com base em critérios menos rígidos que os de patente e ostensiva violação da Constituição; (iii) a imposição de condutas ou de abstenções ao Poder Público, notadamente em matéria de políticas públicas. $^{20}$

No plano prático,

[...] o ativismo do juiz atua sobre o comportamento deste no processo, em busca de um direito judicial, menos submisso às leis ou à doutrina estabelecida e às convenções conceituais. Não importa numa simples, embora ágil, aplicação da norma e que a deixe inalterada. Nem é atitude voluntariosa, mas tomada de consciência no presente e diretriz de decisões futuras. ${ }^{21}$

Entre as causas do ativismo judicial, podemos destacar o incremento progressivo dos Poderes Legislativo e Executivo, justificando a necessidade de crescimento do Judiciário para balanceamento do sistema, bem como a insatisfação do povo em relação à atuação dos outros ramos do Poder. ${ }^{22}$

A atuação insatisfatória dos Poderes Executivo e Legislativo talvez seja o principal motivo do ativismo judicial, oportunidade em que o juiz faz as vezes do legislador ou do administrador público. Outro problema que fomenta o ativismo judicial é a crise por que passam os demais Poderes, frequentemente envolvidos

${ }^{20}$ BARROSO, Luís Roberto. Curso de direito constitucional contemporâneo: os conceitos fundamentais e a construção do novo modelo. São Paulo: Saraiva, 2009. p. 283-284.

${ }^{21}$ LEITE, Evandro Gueiros. Ativismo judicial. BDJur, Brasília, maio 2008. Disponível em: <http://bdjur.stj.gov.br/xmlui/bitstream/handle/2011/16980/Ativismo_Judicial. pdf? sequence=1>. Acesso em: 25 ago. 2010.

${ }^{22}$ LEITE, Evandro Gueiros. Ativismo judicial. BDJur, Brasília, maio 2008. Disponível em: <http://bdjur.stj.gov.br/xmlui/bitstream/handle/2011/ 16980/Ativismo_Judicial. pdf? sequence $=1>$. Acesso em: 25 ago. 2010 
em escândalos dos mais variados tipos, o que, aparentemente, legitima a interferência do Poder Judiciário.

E essa interferência, todavia, causa um círculo vicioso, pois o Poder Executivo e o Legislativo não cumprem a contento suas funções, exigindo a interferência do juiz, o que estimula a negligência dos Poderes faltantes, que encontram no Judiciário a solução para as suas incúrias.

Melhor seria que o Judiciário remetesse ao foro adequado a solução para as omissões dos demais Poderes, especialmente quando afeta a seara política. De fato, em homenagem ao princípio democrático, melhor seria que o Supremo Tribunal Federal, por exemplo, em vez que atuar como legislador positivo, remetesse ao foro competente questões como proibição do nepotismo, uso de algemas, direito de greve no serviço público, fidelidade partidária, uso de células tronco etc.

O risco que corremos com o ativismo judicial é o desrespeito ao princípio democrático, pois a legitimidade do Poder Judiciário é apenas indireta, na medida em que os juízes atuam e decidem de acordo com aquilo que foi previsto pelo legislador. Ademais, o vácuo deixado pelo administrador ou pelo legislador, ou a sua atuação desastrada no campo político, não garantem uma atuação acertada do juiz, que também apresenta as mesmas imperfeições, pois integra a mesma sociedade.

O ativismo judicial também pode comprometer o princípio da separação de poderes, segundo o qual as funções do Estado devem ser exercidas por órgãos distintos, de forma independente e harmônica.

Embora a separação de poderes tenha como pressuposto a ideia de limitação e controle, “[...] cada órgão de poder realiza uma atividade, especializando nela de forma a melhorar a sua eficácia" ${ }^{23}$

${ }^{23}$ AGRA, Walber de Moura. Manual de direito constitucional. São Paulo: Revista dos Tribunais, 2002. p. 129. 
O objetivo dessa separação é preservar a autonomia e independência de cada órgão de poder no exercício de suas funções, sem interferência de um sobre o outro, mas com controles recíprocos, a fim de evitar o arbítrio.

Esse controle recíproco somente se justifica para evitar abusos, jamais com o propósito de usurpação de poder:

A flexibilização da regra-parâmetro, fato indisputável no direito constitucional contemporâneo, encontra, pois, limites na idéia-fim do princípio: limitação do poder. De outro lado, a interferência de um poder sobre o outro somente será admissível em tese, quando vise realizar a idéia-fim, seja para impedir abusos de poder, seja para propiciar real harmonia no relacionamento entre os poderes, seja ainda para garantir as liberdades e assegurar o pleno exercício das funções próprias. ${ }^{24}$

Assim, apenas em caráter excepcional será possível a interferência de um poder sobre o outro, já que a ideia de separação de poderes justifica-se especialmente para prevenir abusos, o que nem sempre ocorre nas situações de ativismo judicial.

\section{Segundo Antoine Garapon,}

[...] o sucesso da justiça é inversamente proporcional ao descrédito que afeta as instituições políticas clássicas, causado pela crise de desinteresse e pela perda do espírito público. A posição de um terceiro imparcial compensa o 'déficit democrático' de uma decisão política agora voltada para a gestão e fornece à sociedade a referência simbólica que a representação nacional lhe oferece cada vez menos. ${ }^{25}$

Por outro lado,

[...] À justiça não cabe resolver todos os problemas, dar a última palavra em matéria de ciência ou de história, definir o bem político e responsabilizar-se pelo bem estar

\footnotetext{
${ }^{24}$ FERRAZ, Anna Cândida da Cunha. Conflito entre poderes: o poder congressual de sustar atos normativos do Poder Executivo. São Paulo: Revista dos Tribunais, 1994. p. 14.

${ }^{25}$ GARAPON, Antoine. O juiz e a democracia: o guardião das promessas. 2. ed. Rio de Janeiro: Revan, 2001. p. 48.
} 
das pessoas. Ela não o pode e não o deve, sob pena de mergulhar-nos num inferno sofista frustrante, estéril e destruidor, que ninguém deseja. ${ }^{26}$

O ativismo significa, na verdade, uma forma de expressão de ideologias, cujo debate é transferido ao Judiciário quando deveria ser remetido ao foro apropriado, qual seja, o Poder Legislativo ou Executivo.

O ativismo decorre da constitucionalização do direito, que significa o efeito expansivo das normas constitucionais, cujas regras e princípios se irradiam por todo o sistema jurídico.

A constitucionalização é fenômeno positivo, pois é compatível com o estado democrático e com a maior realização dos direitos fundamentais. Todavia, a constitucionalização exacerbada pode trazer consequências negativas, entre elas o esvaziamento do poder das maiorias pelo engessamento da legislação ordinária, bem como em face do decisionismo judicial, potencializado pela textura aberta e vaga das normas constitucionais. ${ }^{27}$

Esse estado de constitucionalismo contemporâneo ou neoconstitucionalismo convive com um conflito de caráter geral que diz respeito ao próprio papel da Constituição, consubstanciado em duas ideias antagônicas: o substancialismo e o procedimentalismo.

A primeira delas sustenta que cabe à Constituição impor ao cenário político um conjunto de decisões valorativas que se consideram essenciais e consensuais. Essa primeira concepção pode ser descrita, por simplicidade, como substancialista. Um grupo importante de autores, no entanto, sustenta que apenas cabe à Constituição garantir o funcionamento adequado do sistema de participação democrático, ficando a cargo da maioria, em cada momento histórico, a definição de seus valores e de suas opções políticas. Nenhuma geração poderia impor à

${ }^{26}$ GARAPON, Antoine. O juiz e a democracia: o guardião das promessas. 2. ed. Rio de Janeiro: Revan, 2001. p. 265.

${ }^{27}$ BARROSO, Luís Roberto. Curso de direito constitucional contemporâneo: os conceitos fundamentais e a construção do novo modelo. São Paulo: Saraiva, 2009. p. 391 
seguinte suas próprias convicções materiais. Esta segunda forma de visualizar a Constituição pode ser designada de procedimentalismo. ${ }^{28}$ (grifo do autor).

Assim, pode-se perceber que uma visão fortemente substancialista tenderá a justificar um controle de constitucionalidade mais rigoroso e abrangente dos atos e normas produzidos no âmbito do estado, ao passo que uma percepção procedimentalista conduzirá a uma postura mais deferente acerca das decisões dos Poderes Públicos. ${ }^{29}$

Todavia, em um estado democrático não se pode pretender que a Constituição invada o espaço da política em uma versão de substancialismo radical e elitista, em que as decisões políticas são transferidas, do povo e de seus representantes, para os juristas e operadores do direito em geral, uma vez que a definição dos gastos públicos é um momento de deliberação político-majoritária, ainda que essa deliberação não esteja livre de alguns condicionantes político-constitucionais. ${ }^{30}$

\section{A autolimitação judicial}

Segundo Canotilho

[...] o princípio da autolimitação judicial é outro dos princípios importados da jurisprudência norte-americana e fundamentalmente reconduzível ao seguinte: os juízes devem autolimitar-se à decisão de questões judiciais $e$ negar a justiciabilidade das questões políticas. O princípio

\footnotetext{
${ }^{28}$ BARCELLOS, Ana Paula de. Neoconstitucionalismo, direitos fundamentais e controle de políticas públicas. Revista Diálogo Jurídico, Salvador, n. 15, jan./mar. 2007, p. 7. Disponível em: <http://www.direitopublico.com.br/ pdf_seguro/artigo_controle_pol_ ticas_p_blicas_.pdf $>$. Acesso em: 02 set. 2010.

${ }^{29}$ BARCELLOS, Ana Paula de. Neoconstitucionalismo, direitos fundamentais e controle de políticas públicas. Revista Diálogo Jurídico, Salvador, n. 15, jan./mar. 2007, p. 9. Disponível em: <http://www.direitopublico.com.br/pdf_seguro/artigo_controle_pol_ ticas_p_blicas_.pdf>. Acesso em: 02 set. 2010.

${ }^{30}$ BARCELLOS, Ana Paula de. Neoconstitucionalismo, direitos fundamentais e controle de políticas públicas. Revista Diálogo Jurídico, Salvador, n. 15, jan./mar. 2007, p. 13-14. Disponível em: <http://www.direitopublico.com.br/pdf_seguro/artigo_controle_pol_ ticas_p_blicas_.pdf>. Acesso em: 02 set. 2010.
} 
foi definido pelo juiz Marshall, como significando haver certas 'questões políticas' da competência do Presidente, em relação às quais não pode haver controlo jurisdicional. ${ }^{31}$ (grifos originais)

Barroso esclarece que:

[...] o oposto do ativismo é a auto-contenção judicial, conduta pela qual o Judiciário procura reduzir ao mínimo sua interferência nas ações dos outros Poderes. Por essa linha, juízes e tribunais (i) evitam aplicar diretamente a Constituição a situações que não estejam no seu âmbito de incidência expressa, aguardando o pronunciamento do legislador ordinário; (ii) utilizam critérios rígidos e conservadores para a declaração de inconstitucionalidade de leis e atos normativos; e (iii) abstêm-se de interferir na definição das políticas públicas. ${ }^{32}$

Todavia, a autolimitação ou autocontenção judicial (self-restraint) cada vez é menos praticada pela justiça brasileira, pois a tendência é no sentido de se alargar o âmbito de atuação do Judiciário em nome da inafastabilidade da tutela jurisdicional, com a consequente restrição do exercício da política pelos verdadeiros titulares em desprestígio ao princípio democrático.

A atuação do Poder Judiciário pode advir de três situações distintas, a saber: quando não há manifestação do legislador; quando há dispositivo legal, mas em desacordo com norma constitucional; quando há dispositivo legal, mas moralmente questionável.

Como guardião da Constituição, o Judiciário pode analisar a constitucionalidade das leis e atos normativos, mas somente quando em flagrante desacordo com norma constitucional. Nas demais hipóteses, deve remeter a matéria ao foro apropriado em homenagem ao princípio democrático, uma vez que não lhe cabe exercer preferências políticas.

${ }^{31}$ CANOTILHO, José Joaquim Gomes. Direito constitucional e teoria da constituição. 7. ed. Coimbra: Almedina, 2003. p. 1308-1309.

32 BARROSO, Luís Roberto. Curso de direito constitucional contemporâneo: os conceitos fundamentais e a construção do novo modelo. São Paulo: Saraiva, 2009. p. 285. 
Com efeito, a postura de autolimitação decorre da falta de legitimidade democrática do julgador para decidir sobre escolhas feitas pelo povo na pessoa de seus representantes legais, os quais foram democraticamente eleitos para defender os interesses da sociedade.

A lógica própria do ordenamento jurídico brasileiro indica que:

[...] um crescente movimento de limitação dos tribunais, motivada acima de tudo pelo bom funcionamento dos arranjos institucionais. Ou seja, se o funcionamento dos poderes é adequado, não há por que promover a intervenção do Judiciário na atuação do Executivo ou do Legislativo, não há por que proporcionar a supremacia do poder eminentemente jurídico sobre as manifestações típicas da política. $^{33}$

\section{As questões que não devem ser judicializadas}

Ainda que sob a égide da jurisdição constitucional, em que é dado ao Poder Judiciário analisar a constitucionalidade das leis e atos normativos, não é possível ao juiz apreciar algumas matérias sujeitas ao juízo do administrador ou legislador, sob pena de ofensa ao princípio da separação de poderes.

Assim, a fim de compatibilizar a jurisdição constitucional com a democracia, deve o Judiciário compreender que existem matérias que não devem ser judicializadas, pois são atinentes à competência dos demais Poderes.

\subsection{As questões políticas}

O risco da judicialização da política já foi apontado por Karl Schmitt desde o século passado, para quem a criação de um Tribunal Constitucional seria diame-

\footnotetext{
${ }^{33} \mathrm{HORBACH}$, Carlos Bastide. Controle judicial da atividade política: as questões políticas e os atos de governo. Revista de Informação Legislativa, Brasília, ano 46, n. 182, p. 7-16, abr./ jun., 2009.
} 
tralmente oposta ao princípio democrático justamente por permitir a transposição das funções políticas do legislador a um corpo de juízes, que comporiam, assim, em sua categórica designação, uma “aristocracia da toga". ${ }^{34}$

A judicialização da política consiste no debate político na esfera do Judiciário, ocasião em que são discutidas questões que deveriam ser resolvidas na seara apropriada, qual seja, o Poder Executivo ou Legislativo.

A doutrina das questões políticas surgiu na Suprema Corte dos Estados Unidos e estabeleceu uma região impenetrável à autoridade da Justiça, conforme escólio de Rui Barbosa:

Desde MARSHALL, no memorável aresto em que se sagrou a jurisdição dos tribunais contra o exercício inconstitucional das faculdades do governo, ou do Congresso, ficou, ao mesmo tempo, reconhecido existir no domínio desses poderes uma região impenetrável à autoridade da justiça: a região política.

Mas em que termos se deve entender o horizonte desta expressão? Adotada em sua acepção ampla, ela abrangeria no seu raio a esfera inteira da soberania constitucional, baldaria absolutamente a competência, que para o judiciário se reclama, de coibir-lhes as incursões no terreno do direito individual, reduzindo essa competência a nada. O poder executivo e o poder legislativo são órgãos políticos do regímen; política é sua origem, seu carácter, sua atividade; políticas tôdas as suas funções. A se considerar, pois, a êste aspecto a situação desses poderes, não haveria um só de seus atos, para o qual não se pudesse reivindicar imunidade à sindicância dos tribunais; e o ascendente pretendido por êstes, como propugnáculo das garantias constitucionais contra a usurpação do chefe do Estado, ou das assembléias representativas, seria pura e simplesmente uma burla. ${ }^{35}$

Na verdade, quando se diz que não compete ao Poder Judiciário resolver sobre questões políticas, o que se pretende afirmar é que ele não pode intrometer-

\footnotetext{
${ }^{34}$ SCHMITT, Carl. La defensa de la Constitución. Madrid: Tecnos, 1998. p. 245.

${ }^{35}$ BARBOSA, Rui. Trabalhos jurídicos. Rio de Janeiro: Casa de Cultura Rui Barbosa, 1962. v. 11. p. 96.
} 
-se em assuntos encarregados pela Constituição, ou pelas leis, à discrição de outro poder. ${ }^{36}$

Mas, quais questões exclusivamente políticas devem ser excluídas do controle do Poder Judiciário? Com a palavra, Pedro Lessa:

Para se furtar à competência do poder judiciário, não basta que uma questão ofereça aspectos políticos, ou seja suscetível de efeitos políticos. É necessário que seja simplesmente, puramente, meramente política. Quais são as questões exclusivamente políticas? As que se resolvem com faculdades meramente políticas, por meio de poderes exclusivamente políticos, isto é, que não têm como termos correlativos direitos encarnados nas pessoas, singulares ou coletivas, sobre que tais poderes se exercem. Quando à função de um poder, executivo ou legislativo, não corresponde, ou antes, não se opõe um direito, de uma pessoa, física ou moral, que a ação desse poder interessa, um tal poder pressupõe, evidentemente, o arbítrio da autoridade, em quem reside. É um poder discricionário, que, portanto não pode ser restringido pela interferência de outro. Poder meramente político é um poder discricionário. Eis aí uma verdade, atestado por autorizados mestres do direito constitucional norteamericano. Hitchcock: "As questões puramente políticas, isto é, as que são cometidas, pela Constituição ou pelas leis, à discrição, quer do poder executivo, quer do legislativo, não entram na competência dos tribunais". Thayer: "No caso de atos puramente políticos e do exercício de uma ação puramente discricionária (in the case of purely political acts and of the exercise of mere discretion), ainda que se ache violada a Constituição por outros poderes, o judiciário não pode remediar".37

Segundo Carlos Maximiliano:

[...] não é republicano atribuir a última palavra sobre as expressões da vontade popular, traduzidas no voto ou em atos dos mandatários das turbas sem caráter individual, sobre as questões políticas em sua essência e nos seus fins, a uma corporação de indivíduos não eleitos e, ainda mais,

\footnotetext{
${ }^{36}$ MIRANDA, Pontes de. Comentários à Constituição de 1946. 2. ed. rev. e aum. São Paulo: M. Limonad, 1953. v. 2. p. 474-475.

${ }^{37}$ LESSA, Pedro. Do poder judiciário. Brasília: Senado Federal, 2003. p. 57-61.
} 
vitalícios e, portanto, absolutamente independentes da opinião pública. ${ }^{38}$

Com o objetivo de justificar a exclusão de atos do Presidente da Câmara dos Deputados do controle judicial, o Ministro Paulo Brossard assim se expressou:

Dir-se-á que esse entendimento conflita com o princípio segundo o qual nenhuma lesão pode ser excluída de apreciação judicial. Esse conflito, porém, não ocorre no caso concreto, pois, a mesma Constituição que enuncia essa regra de ouro, reserva privativamente a uma e outra Casa do Congresso o conhecimento de determinados assuntos, excluindo-os da competência de qualquer outra autoridade. Assim, no que tange ao processo de responsabilidade do primeiro ao último ato, ele se desenvolve no âmbito do Poder Legislativo, Câmara e Senado, e em nenhum momento percorre as instâncias judiciárias. Como foi acentuado, é uma exceção, mas exceção constitucionalmente aberta, ao monopólio jurisdicional do Poder Judiciário. A lei não poderia dispor assim. A Constituição poderia. Foi o que fez. ${ }^{39}$

Assim, as questões exclusivamente políticas devem ser afastadas da apreciação do Poder Judiciário, pois não lhe é lícito ingressar no campo da política, porque de competência exclusiva dos demais Poderes.

\subsection{As políticas públicas}

Alcindo Gonçalves apresenta uma série de definições de políticas públicas, esclarecendo que elas constituem-se em ações de governo e tendem a focalizar o estado como agente central de sua promoção. Traz o conceito formulado por Fábio Konder Comparato, para quem política pública significa um conjunto de normas tendentes à realização de um objetivo determinado. Apresenta ainda o conceito formulado por Paulo Renato Flores Durán, segundo o qual, política pública é a

${ }^{38}$ MAXIMILIANO, Carlos. Comentários à Constituição brasileira. Porto Alegre: Livraria do Globo, 1929. p. 632.

${ }^{39}$ BRASIL, Supremo Tribunal Federal. Mandado de Segurança n. ${ }^{\circ}$ 20.941/DF, Relator para o acórdão: Min. Sepúlveda Pertence, Brasília, 09 de fevereiro de 1990, Diário de Justiça, 31 ago. 1992. p. 13.582 . 
busca explícita e razoável de um objetivo graças à alocação adequada de meios nos quais a utilização razoável deve produzir consequências positivas. ${ }^{40}$

Como agente encarregado de implementar políticas públicas, o Estado passou a ter um papel assistencialista, de promotor do bem-estar social. É o chamado Welfare State, construção europeia desenvolvida principalmente após a Segunda Guerra Mundial, cuja responsabilidade é no sentido de garantir o bem-estar básico dos cidadãos. ${ }^{41}$

Eros Roberto Grau, por sua vez, esclarece que:

[...] a expressão políticas públicas designa todas as atuações do Estado, cobrindo todas as formas de intervenção do poder público na vida social. E de tal forma, isso se institucionaliza que o próprio direito, neste quadro, passa a manifestar-se como uma política pública - o direito é também, ele próprio, uma política pública. ${ }^{42}$

Por outro lado, de acordo com a clássica teoria da separação de poderes, adotada pela maior parte das Constituições, inclusive a brasileira, a função de administrar a coisa pública cabe ao Poder Executivo, que deve implementar as políticas públicas para promover o bem-estar social, muito embora não se negue ao Judiciário o direito de, excepcionalmente, interferir na sua execução por meio do julgamento das ações que lhe são endereçadas.

Quer-se aqui dizer, apenas, que compete ao Poder Executivo, primordialmente, a função de administrar a coisa pública e, consequentemente, implementar as políticas públicas em benefício da coletividade.

Assim, considerando que a função de implementar políticas públicas pertence ao Poder Executivo, bem como que tais políticas constavam - ou deveriam

${ }^{40}$ GONÇALVES, Alcindo. Políticas públicas e a ciência política. In: BUCCI, Maria Paula Dallari (Org.). Políticas públicas: reflexões sobre o conceito jurídico. São Paulo: Saraiva, 2006. p. 75.

${ }^{41}$ GONÇALVES, Alcindo. Políticas públicas e a ciência política. In: BUCCI, Maria Paula Dallari (Org.). Políticas públicas: reflexões sobre o conceito jurídico. São Paulo: Saraiva, 2006. p. 77.

${ }^{42}$ GRAU, Eros Roberto. O direito posto e pressuposto. 4. ed. São Paulo: Malheiros, 2002. p. 26. 
constar - em um programa de governo previamente elaborado, que foi inclusive a causa do sucesso nas eleições, pode-se concluir que somente nos casos em que as políticas públicas prometidas não estiverem sendo executadas poderá o Judiciário interferir.

Em princípio, o acerto ou desacerto da política pública adotada não poderá ser objeto de controle judicial, especialmente porque o governante foi eleito e representa a vontade popular, sob pena de afronta ao princípio democrático, salvo nos casos de políticas públicas teratológicas ou em flagrante contrariedade à Constituição.

Portanto, o controle judicial sobre as políticas públicas seria impróprio, uma vez que a formulação das políticas públicas cabe, em regra, ao Poder Executivo, dentro de marcos definidos pelo Poder Legislativo, conforme lição de Canotilho:

O relevo modesto da inconstitucionalidade por omissão prova as dificuldades do controlo das políticas públicas. Estas reconduzem-se fundamentalmente a um conjunto de decisões e ações adoptadas pelo Governo para influir sobre o problema. Os juízes não se podem transformar em conformadores sociais, nem é possível, em termo democrático processuais, obrigar juridicamente os órgãos políticos a cumprir um determinado programa de ação. Pode censurar-se, através do controlo de constitucionalidade, actos normativos densificadores de uma política de sinal contrário à fixada nas normas-tarefa da Constituição. Mas a política deliberativa sobre as políticas da República pertence à política e não à justiça. ${ }^{43}$

A polêmica sobre o controle judicial de políticas públicas pode ser sintetizada na seguinte indagação:

Uma vez que a política pública é expressão de um programa de ação governamental, que dispõe sobre os meios de atuação do Poder Público - e, portanto, com grande relevo para a discricionariedade administrativa, amparada pela legitimidade da investidura do governante no poder -,

${ }^{43}$ CANOTILHO, José Joaquim Gomes. Direito constitucional e teoria da constituição. 7. ed. Coimbra: Almedina, 2003. p. 946. 
como pode, e até que ponto, o Poder Judiciário apreciar determinada política pública sem que isso represente invasão indevida na esfera própria da atividade política de governo $?^{44}$

A resposta a tal indagação foi dada por Luís Roberto Barroso ao tratar do tema concernente ao direito à saúde, que pode ser atendido por meio de variadas políticas públicas, a cargo dos respectivos representantes eleitos pelo povo:

Esse primeiro parâmetro decorre também de um argumento democrático. Os recursos necessários ao custeio dos medicamentos (e de tudo o mais) são obtidos através da cobrança de tributos. E é o próprio povo - que paga os tributos - quem deve decidir preferencialmente, por meio de seus representantes eleitos, de que modo os recursos públicos devem ser gastos e que prioridades serão atendidas em cada momento. A verdade é que os recursos públicos são insuficientes para atender a todas as necessidades sociais, impondo ao Estado a necessidade permanente de tomar decisões difíceis: investir recursos em determinado setor sempre implica deixar de investi-los em outros. A decisão judicial que determina a dispensação de medicamento que não consta das listas em questão enfrenta todo esse conjunto de argumentos jurídicos e práticos. ${ }^{45}$

Com efeito, o acerto ou não da política pública adotada deve ser resolvido na seara apropriada - nas urnas ou por meio da manifestação popular, por exemplo, em respeito ao princípio democrático -, sob pena de o

Judiciário transformar-se em administrador público, em afronta ao princípio da separação de poderes.

De fato, nos estados democráticos, a escolha dos governantes, bem como dos respectivos programas de governo, cabe ao povo, que os elege - ou deveria elegê-los - com base no perfil do candidato, que inclui a sua propensão a desen-

${ }^{44}$ BUCCI, Maria Paula Dallari. O conceito de política pública em direito. In: BUCCI, Maria Paula Dallari (Org.). Políticas públicas: reflexões sobre o conceito jurídico. São Paulo: Saraiva, 2006. p. 23.

${ }^{45}$ BARROSO, Luís Roberto. Da falta de efetividade à judicialização excessiva: direito à saúde, fornecimento gratuito de medicamentos e parâmetros para a atuação judicial. Interesse Público, Belo Horizonte, ano 9, n. 46, p. 31-61, nov./dez. 2007. 
volver determinadas políticas públicas, conforme o programa do partido do qual ele faz parte.

Assim, por meio do voto, o povo elege o governante, levando em conta também a política pública prometida, de sorte que a execução daquela determinada política pública representa a opção popular, que não deve ser afastada, salvo quando em flagrante confronto com a Constituição ou quando o próprio povo assim o desejar.

A interferência do Judiciário somente pode ser considerada legítima quando o administrador deixa de executar as propostas de governo e as políticas públicas por ele prometidas ou quando as políticas públicas adotadas afastam-se flagrantemente da Constituição.

Ademais, o ato de gerir a coisa pública exige do administrador escolhas difíceis, pois a escassez de recursos obriga-o a privilegiar determinadas políticas públicas em detrimento de outras, mostrando-se inviável censurar ou responsabilizar a Administração Pública por situações que escapam da sua capacidade orçamentária.

A tese da reserva do possível está incorporada na tradição ocidental, assentando-se na ideia de que a obrigação impossível não pode ser exigida (Impossibilium nulla obligatio est - Celso, D. 50, 17, 185), de sorte que a insuficiência de recursos orçamentários não pode ser considerada uma mera falácia. ${ }^{46}$

Portanto, a plena eficácia dos direitos sociais deve ser analisada à luz do princípio da reserva do possível, ou seja, os pleitos deduzidos em face do Estado devem ser logicamente razoáveis e, acima de tudo, é necessário que existam condições financeiras para o cumprimento de obrigações por parte dele, de nada adiantando ordem judicial que não possa ser cumprida pela Administração por falta de recursos. ${ }^{47}$

\footnotetext{
${ }^{46}$ BRASIL. Superior Tribunal de Justiça. Recurso Especial n. ${ }^{\circ} 1185474 / S C$. Relator: Ministro Humberto Martins. Brasília, 20 de abril de 2010. Diário da Justiça eletrônico, 29 abr. 2010. ${ }^{47}$ BRASIL. Superior Tribunal de Justiça. Recurso Ordinário em Mandado de Segurança n. 28.962/MG. Relator: Ministro Benedito Gonçalves. Brasília, 25 ago. 2009. Diário de Justiça eletrônico, 03 set. 2009.
} 
Contudo, não basta por parte do estado a simples alegação de insuficiência de recursos, mas a comprovação de sua real inexistência, também chamada de exaustão orçamentária.

Conforme esclarece Eros Roberto Grau, a exaustão orçamentária “[...] é a situação que se manifesta quando inexistirem recursos suficientes para que a Administração possa cumprir determinada ou determinadas decisões judiciais. Não há, no caso, disponibilidade de caixa que lhe permita cumpri-las". ${ }^{48}$

Todavia, existindo o problema da escassez de recursos para a definição do patamar mínimo a permitir a superação da limitação imposta pela reserva do possível, o parâmetro demarcatório é o princípio da dignidade da pessoa humana, o qual representaria o verdadeiro limite à restrição dos

direitos sociais, de sorte que na esfera das condições existenciais mínimas encontra-se um claro limite à liberdade de conformação do legislador. ${ }^{49}$

Por outro lado, conforme entendeu o tribunal alemão, “[...] a prestação reclamada deve corresponder ao que o indivíduo pode razoavelmente exigir da sociedade, de tal sorte que, mesmo em dispondo o estado de recursos e tendo poder de disposição, não se pode falar em uma obrigação de prestar algo que não se mantenha nos limites do razoável".50

Assim, se por um lado a aplicação da teoria da reserva do possível implica reconhecer a inexistência de supremacia absoluta dos direitos fundamentais em toda e qualquer situação, por outro, pode-se afirmar a inexistência da supremacia

${ }^{48}$ GRAU, Eros Roberto. Despesa pública: conflito entre princípios e eficácia das regras jurídicas: o princípio da sujeição da Administração às decisões do Poder Judiciário e o princípio da legalidade da despesa pública. Revista Trimestral de Direito Público, São Paulo, n. 2, p. 130-148, 1993. p. 144.

${ }^{49}$ SARLET, Ingo Wolfgang. A eficácia dos direitos fundamentais. 2. ed. rev. atual. Porto Alegre: Livraria do Advogado, 2001. p. 323.

${ }^{50}$ SARLET, Ingo Wolfgang. A eficácia dos direitos fundamentais. 2. ed. rev. atual. Porto Alegre: Livraria do Advogado, 2001. p. 265. 
absoluta do princípio da limitação orçamentária como óbice à efetivação dos direitos fundamentais.

Com efeito, as políticas públicas destinam-se a promover também os direitos sociais, que demandam uma atuação positiva do estado, razão pela qual devem ter um desenvolvimento progressivo em face das limitações impostas pela ideia da reserva do possível.

Tanto é assim que a própria Convenção Americana Sobre Direitos Humanos, em seu artigo 26, preconiza que os estados signatários comprometem-se a adotar providências, tanto no âmbito interno como mediante cooperação internacional, especialmente econômica e técnica, a fim de conseguir progressivamente a plena efetividade dos direitos que decorrem das normas econômicas, sociais e sobre educação, ciência e cultura, constantes da Carta da Organização dos Estados Americanos, reformada pelo Protocolo de Buenos Aires, na medida dos recursos disponíveis, por via legislativa ou por outros meios apropriados.

Portanto, as políticas públicas adotadas pelo administrador podem não atender satisfatoriamente os direitos sociais, mas nem por isso devem ser afastadas e substituídas pelo Poder Judiciário sob a simples alegação de seu desacerto, salvo quando, vale a pena repetir, teratológicas ou fragrantemente contrárias à Constituição Federal.

Por outro lado, quando a política pública adotada for razoável, não é lícito ao Judiciário afastá-la para atender interesses individuais, em prejuízo do coletivo, semeando a anarquia nas contas públicas.

\section{Conclusão}

A atuação do Poder Judiciário, em algumas questões, tem sido objeto de grandes polêmicas. $\mathrm{O}$ debate polariza-se entre aqueles que defendem a sua atuação, livre e ilimitada, e outros que pregam a sua autolimitação. 
A polêmica remonta à discussão entre constitucionalismo e democracia, levada a efeito por Karl Schmitt e Hans Kelsen no século passado, sobre quem deveria ser o guardião da Constituição.

Todavia, a despeito de ter prevalecido a tese da jurisdição constitucional, é possível compatibilizá-la com o princípio democrático, bastando que seja observado o princípio da autolimitação judicial.

O ativismo judicial, como forma de expressão de ideologias, deve ser visto com reservas, sob pena de desrespeito ao princípio democrático, pois a legitimidade do Poder Judiciário é apenas indireta.

Em um estado democrático, não se pode pretender que a Constituição invada o espaço da política em uma versão de substancialismo radical e elitista, em que as decisões políticas são transferidas, do povo e de seus representantes, para os juristas e operadores do direito em geral, uma vez que a definição dos gastos públicos é um momento de deliberação político-majoritária, ainda que essa deliberação não esteja livre de alguns condicionantes político-constitucionais.

Os juízes devem autolimitar-se à decisão de questões jurídicas e negar a justiciabilidade das questões políticas, conforme advertência de Canotilho.

As questões exclusivamente políticas e a análise do mérito das políticas públicas devem ficar fora do campo de atuação do Poder Judiciário, não devendo ser judicializadas.

O acerto ou desacerto da política pública adotada não poderá ser objeto de controle judicial, especialmente porque o governante foi eleito e representa a vontade popular, sob pena de afronta ao princípio democrático, salvo nos casos de políticas públicas teratológicas ou em flagrante contrariedade à Constituição.

Quando a política pública adotada for razoável, não é lícito ao Judiciário afastá-la para atender interesses individuais, em prejuízo do coletivo, semeando a anarquia nas contas públicas. 
A aplicação da teoria da reserva do possível, por um lado, implica reconhecer a inexistência de supremacia absoluta dos direitos fundamentais em toda e qualquer situação e, por outro, a inexistência de supremacia absoluta do princípio da limitação orçamentária como óbice à efetivação dos direitos fundamentais.

Observando-se o princípio da autolimitação judicial, será possível legitimar o controle jurisdicional das políticas públicas sem desrespeitar o princípio democrático e sem ofender o princípio da separação de poderes.

\section{Judicial control of public politics}

Abstract

We have seen the Judiciary, currently an active role in the institutional life of Brazil. However, this judicial activism, sometimes applauded, sometimes criticized, should be viewed with caution. In fact, the action of the Judiciary, though sometimes necessary, cannot invade the field of action of other Powers, otherwise undermine democracy and represent the legalization of politics, as warned Carl Schmitt. Thus, the merit of public politics, referent the competence of the government, must stay out of court control. The object of this study will thus establish the limits of judicial review in relation to public politics.

Keywords: Democracy. Constitutionalism. Judicial activism. Self limits. Public politics.

\section{Referências}

AGRA, Walber de Moura. Manual de direito constitucional. São Paulo: Revista dos Tribunais, 2002.

BARBOSA, Rui. Trabalhos jurídicos. Rio de Janeiro: Casa de Cultura Rui Barbosa, 1962. v. 11. 
BARBOZA, Estefânia Maria de Queiroz. Jurisdição constitucional: entre constitucionalismo e democracia. Belo Horizonte: Fórum, 2007.

BARCELLOS, Ana Paula de. Neoconstitucionalismo, direitos fundamentais e controle de políticas públicas. Revista Diálogo Jurídico, Salvador, n. 15, jan./mar. 2007, p. 7. Disponível em: <http://www.direitopublico.com.br/pdf_seguro/artigo_ controle_pol_ticas_p_blicas_.pdf>. Acesso em: 02 set. 2010.

BARROSO, Luís Roberto. Curso de direito constitucional contemporâneo: os conceitos fundamentais e a construção do novo modelo. São Paulo: Saraiva, 2009.

BARROSO, Luís Roberto. Da falta de efetividade à judicialização excessiva: direito à saúde, fornecimento gratuito de medicamentos e parâmetros para a atuação judicial. Interesse Público, Belo Horizonte, ano 9, n. 46, p. 31-61, nov./dez. 2007.

BARROSO, Luís Roberto. Judicialização, ativismo judicial e legitimidade democrática. Revista Atualidades Jurídicas, Brasília, n. 4, p. 6, jan./fev. 2009. Disponível em: <http://www.oab.org.br/oabeditora/users/revista/123 5066670174218181901.pdf>. Acesso em: 30 ago. 2010

BRASIL. Superior Tribunal de Justiça. Recurso Especial n.o 1185474/SC. Relator: Ministro Humberto Martins. Brasília, 20 de abril de 2010. Diário da Justiça eletrônico, 29 abr. 2010.

BRASIL. Superior Tribunal de Justiça. Recurso Ordinário em Mandado de Segurança n. ${ }^{\circ}$ 28.962/MG. Relator: Ministro Benedito Gonçalves. Brasília, 25 agosto de 2009. Diário de Justiça eletrônico, 03 set. 2009.

BRASIL. Supremo Tribunal Federal. Mandado de Segurança n. ${ }^{\circ}$ 20.941/DF. Relator para o acórdão: Min. Sepúlveda Pertence. Brasília, 09 de fevereiro de 1990. Diário de Justiça, p. 13.582, 31 ago. 1992,

BUCCI, Maria Paula Dallari (Org.). Políticas públicas: reflexões sobre o conceito jurídico. São Paulo: Saraiva, 2006.

BUCCI, Maria Paula Dallari. O conceito de política pública em direito. In: BUCCI, Maria Paula Dallari (Org.). Políticas públicas: reflexões sobre o conceito jurídico. São Paulo: Saraiva, 2006.

BULOS, Uadi Lammêgo. Constituição federal anotada. 3. ed., rev. e atual. São Paulo: Saraiva, 2001. 
CANOTILHO, José Joaquim Gomes. Direito constitucional e teoria da constituição. 7. ed. Coimbra: Almedina, 2003.

DELGADO, José Augusto. Ativismo Judicial: o papel político do poder judiciário na sociedade contemporânea. In: JAYME, Fernando Gonzaga; FARIA, Juliana Cordeiro de; LAUAR, Maira Terra. Processo civil novas tendências: homenagem ao professor Humberto Theodoro Júnior. Belo Horizonte: Del Rey, 2008, p. 319-338.

DI PIETRO, Maria Sylvia Zanella. Direito administrativo. 20. ed. São Paulo: Atlas, 2007.

FERRAZ, Anna Cândida da Cunha. Conflito entre poderes: o poder congressual de sustar atos normativos do Poder Executivo. São Paulo: Revista dos Tribunais, 1994.

GARAPON, Antoine. O juiz e a democracia: o guardião das promessas. 2. ed. Rio de Janeiro: Revan, 2001.

GONÇALVES, Alcindo. Políticas públicas e a ciência política. In: BUCCI, Maria Paula Dallari (Org.). Políticas públicas: reflexões sobre o conceito jurídico. São Paulo: Saraiva, 2006.

GRAU, Eros Roberto. Despesa pública: conflito entre princípios e eficácia das regras jurídicas: o princípio da sujeição da Administração às decisões do Poder Judiciário e o princípio da legalidade da despesa pública. Revista Trimestral de Direito Público, São Paulo, n. 2, p. 130-148, 1993.

GRAU, Eros Roberto. O direito posto e pressuposto. 4. ed. São Paulo: Malheiros, 2002.

HORBACH, Carlos Bastide. Controle judicial da atividade política: as questões políticas e os atos de governo. Revista de Informação Legislativa, Brasília, ano 46, n. 182, p. 7-16, abr./jun. 2009.

KELSEN, Hans. Jurisdição constitucional. São Paulo: M. Fontes, 2007.

LEITE, Evandro Gueiros. Ativismo judicial. BDJur, Brasília, maio 2008. Disponível em: <http://bdjur.stj.gov.br/xmlui/bitstream/handle/2011/ 16980/Ativismo_ Judicial.pdf? sequence=1>. Acesso em: 25 ago. 2010 .

LESSA, Pedro. Do poder judiciário. Brasília: Senado Federal, 2003. 
MALISKA, Marcos Augusto. Acerca da legitimidade do controle da constitucionalidade. Justitia, São Paulo, v. 63, n. 193, p. 81-96, jan./mar. 2001. Disponível em: <http://bdjur.stj.gov.br/dspace/handle/2011/23783>. Acesso em: 09 jun. 2010.

MAXIMILIANO, Carlos. Comentários à constituição brasileira. Porto Alegre: Livraria do Globo, 1929.

MEIRELLES, Hely Lopes. Direito administrativo brasileiro. 24. ed. São Paulo: Malheiros, 1999.

MENDES, Gilmar Ferreira; COELHO, Inocêncio Mártires; BRANCO, Paulo Gustavo Gonet. Curso de direito constitucional. 4. ed. rev. e atual. São Paulo: Saraiva, 2009.

MIRANDA, Pontes de. Comentários à Constituição de 1946. 2. ed. rev. e aum. São Paulo: M. Limonad, 1953. v. 2.

SARLET, Ingo Wolfgang. A eficácia dos direitos fundamentais. 2. ed. rev. atual. Porto Alegre: Livraria do Advogado, 2001.

SCHMITT, Carl. La defensa de la Constitución. Madrid: Tecnos, 1998.

SILVA, José Afonso da. Curso de direito constitucional positivo. 19. ed. rev. e atual. São Paulo: Malheiros, 2001. 